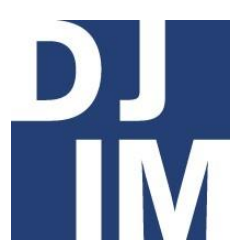

Volume 14

Spring

2018

djim.management.dal.ca |

\title{
Peering into the Private Lives of Judges: Reconciling Judicial Accountability and Privacy
}

Nancy Li

School of Information Management, School of Law, Dalhousie University

\begin{abstract}
Members of the Canadian courts are expected to maintain a rigorous degree of professionalism and good conduct in maintaining an independent, impartial and accountable judiciary. Yet, judges bring their diverse past experiences and values to bench and lead complex lives off the bench. Through examination of the judicial discipline of former Justice Lori Douglas in 2010, this paper makes a two-fold argument. Firstly, although the integrity of conduct by members of the judiciary must be held to the highest standard of public accountability, diverse backgrounds and lived experiences of judges allow for better informed decision-making and thereby, increase public confidence. Secondly, privacy of non-judicial activities ought to be protected to the extent that such activities do not erode public confidence in the judiciary. The diversity of lived experiences and backgrounds of judges is what makes the bench representative and credible in the eyes of Canadians. It is important that policies of the Canadian Judicial Council address these issues in creating workable inquiry and disciplinary procedures that truly further judicial accountability in the eyes of the public in a manner that is efficient yet mitigates harm to individual judges under investigation.
\end{abstract}

\section{Introduction}

In 2010, former Justice Lori Douglas came under the scrutiny of the Canadian Judicial
Council (CJC), when she was an associate chief justice of the Manitoba Court of Queen's Bench. The CJC is an agency created by Parliament that sets policies for 
the federal judicial system. The complaint against Justice Lori Douglas arose after her late husband, who took nude photos of her, posted them to the Internet without her knowledge or permission. Douglas faced allegations of failing to disclose the photos when she applied to become a judge, as the pictures could undermine public confidence in the Canadian justice system (Huffington Post, 2014). By examining the case of Lori Douglas within the context of the Canadian judiciary, this paper makes a two-fold argument. Firstly, although the integrity of conduct by members of the judiciary must be held to the highest standard of public accountability, diverse backgrounds and lived experiences of judges allow for better informed decisionmaking and thereby, increase public confidence. Secondly, privacy of nonjudicial activities ought to be protected to the extent that such activities do not erode public confidence in the judiciary.

The CJC complaint against Douglas was centered on the allegation that, prior to her appointment to the bench, she was involved in a sexual harassment claim (Blatchford, 2014). Douglas denies taking part in the alleged harassment (CJC, 2014). Another part of the complaint involved the nude photos of Douglas that her husband uploaded to the internet. Douglas argued that she neither had knowledge nor gave consent to the posting of the photos or the use of them to solicit the interest of the complainant (Blatchford, 2014). Among the questions raised in the inquiry was whether Douglas should have publicly disclosed on her judicial appointment application the photos on the Internet, as an aspect of her history that may negatively impact the judiciary (CJC, 2014).

\section{Structure of the Canadian Judiciary}

An relationship between the legislative, executive, and judicial branches of government create the structure of the Canadian judiciary. The elected government makes and administers our laws in the legislative and executive branches, and the courts apply those laws. A judge's role is to to resolve legal disputes between parties by applying the law to facts. Section 99 of the Constitution Act provides for the appointment of judges to the bench. The Judges Act is the statute that establishes how judges are appointed, the age of retirement, remuneration of judges, and the Canadian Judicial Council's mandate. Once appointed, a judge may remain on the bench until age 75 . The federal government appoints judges who hear cases in Canadian superior courts.

The Canadian Judicial Council is responsible for the oversight and discipline of federally appointed judges. A judge can be removed from office only if an independent investigation shows that they have not met the high standard of personal conduct required of judges, both in court and in public (CJC, 2017). Following a CJC recommendation to Parliament (via the Minister of Justice), the judge may be removed from office (CJC, 2017).

Peering into the Private Lives of Judges 


\section{Judicial Independence and Accountability}

Judicial independence is paramount in the Canadian judicial system. The Canadian Constitution provides that the judiciary is separate from, and independent of, the legislative and executive branches of government. The judiciary interprets laws created by government on complex social issues and matters involving the allocation of scarce resources. Judicial independence means that judges are not subject to pressure and influence, and are free to make decisions based solely on facts and the law. Judicial conduct demands independence to provide judges with the ability to deliver judgements without fear of retaliation or punishment. The CJC defines independence as security of tenure, financial security and administrative independence (CJC, 2017).

Although securing judicial independence is important, it can be dangerous if such protection is used to shield against accountability. Judicial independence, as a central tenet of the Canadian system, entails that judges are not immediately accountable to the legislative or executive branches. However, this does not mean that judicial conduct is immune from oversight and review. The Canadian Judicial Council provides internal peer review of judicial conduct of federally appointed judges, traditionally behind closed doors (CJC, 2017).

Peering into the Private Lives of Judges

\section{The Canadian Judicial Council}

\section{Composition}

Parliament created the Canadian Judicial Council by statute in 1971 (Friedland, 1995). The Canadian Judicial Council is composed of 39 members and is chaired by the Chief Justice of the Supreme Court of Canada. Membership to the council consists of the chief justices, associate chief justices, and some senior judges from provincial and federal superior courts across Canada.

\section{Mandate and Powers}

Canadian judges are expected to maintain a rigorous degree of professionalism and good conduct. The main objectives of the Canadian Judicial Council, as mandated by the Judges Act, are to set policies and promote efficiency, uniformity, and accountability to improve the quality of judicial service in Canadian superior courts. The Council's powers are set out in Part II of the Judges Act. Under the Act, the CJC has the authority to investigate complaints about the conduct (but not decisions) of of federally appointed judges in Canada. After investigation of a complaint, the Inquiry Committee reports back to the Council with its recommendations, including a possible recommendation that "...the judge be removed from office" under section 65 of the Judges Act.

\section{Limitations}

The Canadian judiciary, is to a large extent a self-disciplining body. Once appointed, it is difficult to remove a sitting judge. The effectiveness of self-discipline in furthering 
judicial accountability has been debated. Today, the only procedure to remove a superior court judge in Canada, as set out in section 99 of the Constitution Act, is ... "by the Governor General on Address of the Senate and the House of Commons (joint address)." The efficacy of the joint address process in practice remains unclear. Since Confederation, there have only been five cases in which Parliament has considered the removal of a superior court judge and there has never been a case in which a superior court judge was so removed. In all cases thus far, the judges investigated for alleged misconduct have resigned before Parliament could vote on their removal (Friedland, 1995). Section 71 of the Judges Act specifically states that nothing contained in the Act ... "affects any power, right or duty of the House of Commons, the Senate or the Governor in Council in relation to the removal from office of a judge ..." According to Friedland (1995), the problem with the joint address procedure is that it is a relatively low threshold procedure, requiring only a majority vote of the House and Senate.

During the Douglas Inquiry, the limitations of the CJC as a self-regulating body operating behind closed doors was illuminated when the first round of hearings that began in 2012 collapsed amid accusations raised by Douglas that the fivejudge committee was biased against her (CBC, 2014). The committee's independent counsel resigned, followed by the resignation of panel members. A new panel was subsequently appointed, comprising of 4 two male judges and a female lawyer. Also appointed was a female lawyer to act as independent counsel to the panel (CBC 2014). This turbulent investigation process reveals the limitations of internal selfdiscipline and the lack of an external, neutral arbiter to oversee judicial conduct.

Political implications also arise from the delays and perceived inefficiency of a judicial investigation process funded by public spending. This raises the issue of the "...difference in the relative power enjoyed by the various groups, as between, for example: individuals/organizations subject to legislation which is part of the policy, and the government which determines the policy" (Orna, 2008, p. 551). In this case, the members of the judiciary are pitted against tax payers who are funding the judicial investigation process, yet are not participants in the matter and do not have a say in the result. Procedural flaws may provoke frustration and political criticism as the CJC Inquiry implicates public spending required to cover the costs of a lengthy investigation over a judge who ultimately elected to retire in less than six months later. The $\$ 3$ million that had been spent on the Douglas case did not include her salary, which she continued to receive in full during the investigation (CBC, 2014). According to the judicial renumeration scheme, the salary for an associate chief justice is $\$ 315,900$; certainly not an insignificant sum in the eyes of the public (Judges Act, 1985).

Peering into the Private Lives of Judges 


\section{The Douglas Inquiry}

In 2000, Justice Bastarache argued in Arsenault-Cameron v. Prince Edward Island that

"the duty to be impartial does not mean that a judge does not, or cannot bring to the bench many existing sympathies, antipathities or attitudes... Indeed, even if it were possible, a judge free of this heritage of past experience would probably lack the very qualities of humanity required of a judge."

However, the public response to the Lori Douglas scandal suggests that humanity may not be a quality that is especially prized.

The statement made by Douglas' lawyer to the CJC panel emphasized the excruciating distress and Douglas' inability to withstand additional weeks of hearing into intensely private matters (CBC, 2014). The risk of her intimate images being viewed and discussed by her colleagues and others was crippling and more than she could bear. However, the cost of exoneration from the painful process was to step down from the bench.

The Douglas Inquiry raised the issue of discipline along gender lines and the social implications of CJC policies for women on the bench. Information policies entail relations between groups of people who are parties to them in some way (Orna, 2008, p. 551). Douglas claimed that had she been a man, the reaction to the photos Peering into the Private Lives of Judges would have been different. She claims that the council should have defended her rather than drag her through a messy disciplinary hearing (Puxley, 2016). Douglas is quoted as saying that knowing staff of the Canadian Judicial Council were viewing her photos as part of the hearing was like "torture that's inflicted in war on women." (Puxley, 2016).

After a turbulent process and expenditure of both public funds and judicial resources, the investigation came to a halt in November 2014 when Justice Lori Douglas informed the Council that she had elected early retirement, effective May 2015 (CJC, 2014). As such, the CJC stated that no conclusions should be drawn about the merits of the allegations against Douglas or any of the issues put before the courts (CBC, 2014). The Inquiry Committee stayed its proceedings on grounds that the matter should be resolved, and that this resolution was in the public interest.

\section{Privacy in an Internet Age}

Clear delineation between one's public and private life is made especially stark when one's judicial career demands a high standard of appropriateness that comes nothing short of pristine with regards to online presence. As the ever-expanding growth of the "information society" continues into the twenty-first century, perhaps the standards regarding the online presence of judges will change (Duff, 2004). However, this change will likely be incremental as the legal profession remains 
one of the most conservative professions, especially for members of the judiciary.

In response to the Douglas Inquiry, Alice Woolley, associate law professor at the University of Calgary, opined: "What you do in your bedroom is your business, regardless of whether or not you're a judge." (CBC, 2010). However, according to Woolley, the fact that these photos were circulated on the Internet adds a heightened dimension to the issue. If a prospective judge had been involved in such a situation, it would be inappropriate based on our current norms of judging (CBC, 2010). This raises questions of just how much disclosure is sufficient for an applicant to include while still being able to keep private matters private.

Annalise Acorn, a law and ethics professor at the University of Alberta expressed doubt that "...a person would have the authority to judge others, to send people to jail, to award high amounts of money in damage awards when they had that kind of compromising materials about themselves out in the public sphere." (CBC, 2010). She emphasized that it is immaterial whether the individual personally put the online material in the public sphere (CBC, 2010).

The fact that the pictures have appeared online elevates the severity of the issue of credibility. The speed and ease at which virtual content on the Internet proliferates exacerbates the issue as pictures on the Internet will likely never completely disappear. Although the photos in question have been removed from the pornographic website on which they were posted, it remains unclear whether they have been permanently destroyed or whether they will resurface elsewhere on the Internet.

\section{Implications for Individual Privacy}

To convey the considerable damage on her private life resulting from the Douglas Inquiry, Lori Douglas stated, "I lost my job. I lost my life. I lost my reputation. If it hadn't been for my son, there would have been little reason to keep on." (Welch, 2016). The media's sensationalisation of the case, comparable to the spread of Hollywood gossip and coverage of celebrity scandals, has likely exacerbated the intrusion into Douglas' privacy. A CJC complaint investigation typically spans over a period of three months (CBC, 2010). During those months, both the public and private life of a judge under investigation remains under scrutiny and is subject to media coverage. Douglas's lawyers had fought for a ban on the graphic sex photographs during the hearing ( $C B C$, 2014). To display such private photos to her peers would greatly violate our commonsense notions of reasonable individual privacy. Yet, in that ruling, Federal Court Judge Richard Mosley raised questions about how the hearing would proceed without photos central to the allegations against her (CBC, 2014).

This dissonance between accountability and privacy is one that rears its head in many forms during the investigation of Lori Douglas. Intimate details of her past has Peering into the Private Lives of Judges 
been dug up and displayed for the public consumption, and her judicial role at the time was greatly impacted in a negative way. Her future path remained in limbo during the course of the investigation and took an undesirable turn. Rather than subject herself to further distress and humiliation, Lori Douglas opted to make an agreement to stay the investigation proceedings in exchange for her early retirement in May 2015 (CBC, 2014).

The Douglas complaint begs the question of whether judges can reasonably maintain a private life. $C B C^{\prime}$ 's initial coverage of the story presented the commentary of several law and ethics professors. Professor Arthur Schafer, director of the Centre for Professional and Applied Ethics at the University of Manitoba, claimed [that] if this were disclosed to the application committee, "it is inconceivable that a lawyer who discloses this would become a judge." Conversely, it would also be problematic if no disclosure was made.

Dalhousie University law professor, Wayne Mackay, opined that it is imperative that judicial candidates disclose all relevant information at the outset. Professor MacKay claims that

"In spite of the fact that it's obviously private-and judges still do have the right to a private lifethat kind of picture when it's public, and that kind of information when public, I think it would clearly bring the judicial system or the administration of justice in question, or at least in some people's mind diminish the court's image." (CBC, 2010)

Public confidence in the judiciary is an abstract and ambiguous concept that is illdefined. There are many "publics" in contemporary Canadian society. Legal abstractions such as "public interest" have multiple meanings. How notions of fairness and impartiality of the tribunal are defined likely varies considerably among groups and individuals. "That some judgeshowever few in number is beside the point, for even one rotten judicial apple can go far toward spoiling the entire judicial barrel- fall short of the requisite standards of integrity and proprietary (nebulous and ill-defined though they may be) creates a large part of the problem of public confidence" (Miller, 1970, p. 70).

Miller (1970) proposes that "the point is not whether justice is in fact done; that is important, but only half the picture. Also necessary is a belief - read confidencethat judges are rendering justice" (p. 79). The public is not always capable of appreciating the complexities of judicial decisions, but the literature suggests that there is consensus as to the parameters of what constitutes acceptable judicial conduct. A judge is seen by the public to embody the justice system (CBC, 2010). As such, judicial accountability is not merely achieved by judges adhering to standards of good conduct. Rather, it is actively shaped by what the public perceives is credible and just. 
Judicial ethics tend to distort reality, as a few highly publicized off-bench actions of judges can tarnish the ideal image of courts in the eyes of the public (Miller, 1970). In addition, judges are human beings that bring their diverse past experiences and values to bench and lead complex lives off the bench. However, the very diversity of lived experiences and backgrounds of judges is what makes the bench representative and credible in the eyes of Canadians. It is important that CJC policies take into consideration these issues in creating a workable procedure that will truly further judicial accountability in a manner that is efficient yet mitigates harm to those undergoing investigation.

\section{References}

Arsenault-Cameron v. Prince Edward Island, 2000 SCC 1, [2000] 1 SCR 3.

Blatchford, C. Christie Blatchford on Lori Douglas scandal: Lesson may be that even judges aren't immune to power of sex pictures and the web. Retrieved from http://nationalpost.com/opinion/chr istie-blatchford-real-lesson-of-loridouglas-scandal-may-be-thateven-judges-arent-immune-topower-of-sex-pictures-andthe-web

Canadian Judicial Council. Statement by the Canadian Judicial Council regarding the Inquiry in to the conduct of the Honourable Lori
Douglas. Retrieved from https://www.cjcccm.gc.ca/english/n ews_en.asp?selMenu=news_2014_1 124_en.asp.

Canadian Judicial Council. (2017). Mandate and powers. Retrieved from https://www.cjcccm.gc.ca/english/about_en.asp?sel Menu=about_main_en.asp.

CBC News. Judge Lori Douglas's offer to retire early accepted by judicial panel. Retrieved from http://www.cbc.ca/news/canada/ma nitoba/judge-lori-douglas-s-offerto-retire-early-accepted-by-judicialpanel-1.2846980

CBC News. Nude Photos of Judge Contained in Compliant. Retrieved from

http://www.cbc.ca/news/canada/ma nitoba/nude-photos-of-judgecontained-incomplaint-1.900235

Constitution Act, 1867, 30 \& 31 Vict, c 3, ss $96-100$.

Duff, A. S. (2004). The Past, present and future of information policy, Information Communication and Society, 7(1), 69-87. doi: 10.1080/1369118042000208906

Friedland, M. Discipline, A Place Apart: Judicial Independence and Peering into the Private Lives of Judges 
Accountability in Canada. Ottawa, Ontario: Canadian Judicial Council.

Judges Act. R.S.C., 1985, c. J-1, s 99.

Miller, A. (1970). Public Confidence in the Judiciary: Some Notes and Reflections, Law and Contemporary Problems, 35(1) 69-93. doi: $10.2307 / 1191030$

Orna, E. (2008). Information policies: yesterday, today, tomorrow, Journal of Information Science 34(4), 547565, doi:

10.1177/0165551508092256
Puxley, C. Former Manitoba judge compares disciplinary hearing to 'torture'. Retrieved from http://www.cbc.ca/news/canada/ma nitoba/former-manitoba-judgecompares-disciplinary-hearing-totorture-1.3390836

Welch, A. Former judge Lori Douglas opens up about the hurt caused by CJC hearing. Retrieved from https://www.winnipegfreepress.com /local/Lori- Douglas364299101.html 